\title{
APPLICATION OF COMPUTED TOMOGRAPHY IN THE DIAGNOSIS OF CHRONIC APICAL PERIODONTITIS
}

\author{
Anatoly A. Adamchik, Valerii V. Tairov*, Maria V. Adamchik, \\ Natalya I. Bykova, Ekaterina S. Zaporozhskaya-Abramova, \\ Viktoria A. Ivashenko, Kseniya D. Kirsh, Zhanna V. Solovyeva
}

Federal State Budgetary Educational Institution of Higher Education Kuban State Medical University of Ministry of Healthcare of the Russian Federation, Krasnodar, Russia

\begin{abstract}
The present study is a descriptive comparison of the obtained data for the assessment of the optical density zones of the apical focus of destruction, in chronic apical periodontitis, carried out by the method of cone-beam computed tomography (CBCT) and histological examination of the obtained material after CBCT. The material of the study was extracted teeth with a diagnosis of chronic apical periodontitis with periapical tissues. The assessment of the zones of the apical focus of destruction was carried out in different surfaces of the CBCT. The analysis was carried out by evaluating the values in the center, maximum and minimum on the HU optical unit scale. Histological preparations were obtained after $C B C T$ by removing 30 teeth for medical reasons with the preservation of adjacent tissues. The results of the study demonstrated a diagnostic model with minimal indicators and a statistically significant focal area at $P=0.0008$.
\end{abstract}

Key words: Chronic apical periodontitis diagnosis, computed tomography, optical density, root cyst

\section{INTRODUCTION}

Currently, diagnostic measures aimed at diagnosing chronic destructive periodontitis are far from perfect and require more accurate studies $[1,2]$. The problem of differential diagnosis of such destructive forms of periodontitis as periapical granuloma and root cyst is partially solved by the use of intraoral radiography according to McCall and Wald, described in 1958 [3].

At the same time, it is worth noting that the intraoral radiograph has a number of limitations, in particular, this radiological method does not allow identifying a periapical lesion, due to the presence of distorted dimensions and the lack of clear ideas about the localization of the lesion $[4,5]$.

The scientific literature describes a method of introducing a contrast agent into the periapical focus through the root canal, during X-ray examination, which made it possible to conduct a differential study [6]. It should be noted that the application of the technique of introducing an X-ray contrast agent into the periapical focus allows you to visualize a granuloma as a focus with an irregular shape and ragged borders with different indicators of radiographic density. The root cyst is visualized with this method - round, clear contours with a uniform radiographic density [7-9].

The literature describes a method for diagnosing root cysts and apical granuloma by aspiration of fluid from the periapical focus and its laboratory analysis. The presence of a pale yellow straw-colored liquid containing cholesterol crystals and with a total protein content of 4-11 g. per $100 \mathrm{ml}$ is pathognomonic for the formed cyst [9, 10].

Despite the wide choice, specificity and sensitivity of non-invasive techniques used for the purpose of differential diagnosis of root cyst and apical granuloma, the reliability of each of them is quite low [11]. When conducting a comparative study of diagnostic accuracy, conventional and digital radiography with the results of pathomorphological studies, the following results were demonstrated: the accuracy of intraoral radiography was $48 \%$, digital radiography $58 \%$. Based on this, the histological examination of the biopsy of the lesion can be attributed to the "gold standard" in the diagnosis of a typical form of periapical lesion [12].

At the same time, the appearance of the cone-beam computed tomography (CBCT) technique has advanced the possibilities of X-ray assessment methods to a fundamentally new level. This method allows us to obtain data on the size of the pathological focus in destructive forms of chronic periodontitis, localization of the focus in the spongiose bone or with a violation of the compact plate, and also allows us to detect the presence of periapical radiolution much earlier than it will be visualized on intraoral radiographs $[13,14,15]$. Moreover, with the help of CBCT, it is possible to conduct a quantitative, visual assessment of the density of structures on the Hounsfield scale (HU optical index scale) $[16,18,19,20]$.

\footnotetext{
*tairovvaleriy@mail.ru
} 
Thus, the purpose of this study is to conduct diagnostic accuracy of destructive forms of chronic periodontitis, namely root cyst and periapical granuloma. The optical parameters of CBCT and excision biopsy were compared.

\section{MATERIALS AND METHODS OF RESEARCH}

In order to carry out the clinical and laboratory stage of the study, 30 patients with a preliminary diagnosis of chronic apical periodontitis, who refused conservative treatment, had their affected teeth removed.

All patients who participated in this scientific study were previously informed and gave written consent to its conduct.

This study was approved by the Ethics Committee of the Federal State Budgetary Institution of Higher Education of the Ministry of Health of the Russian Federation (Protocol No. 46 of 29.11.2016).

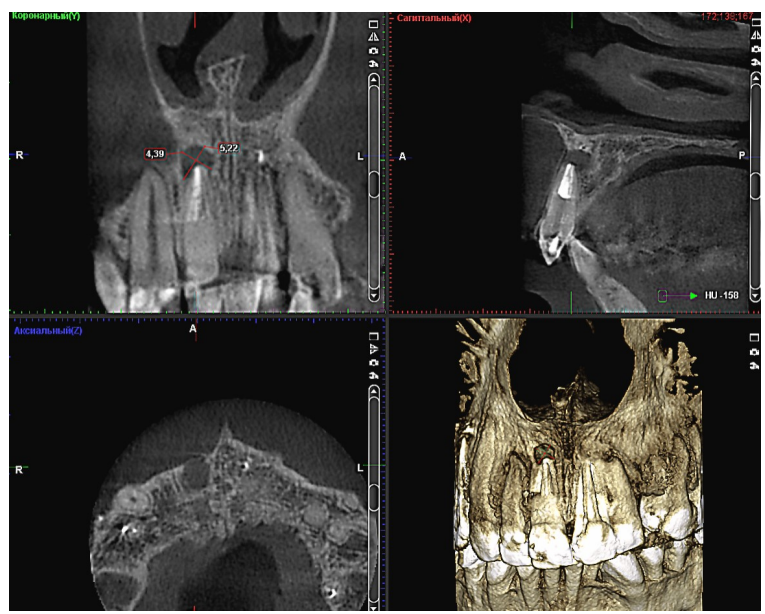

Figure 1. Data from the CBCT examination of the tooth 1.1., when determining the units $\mathrm{HU}=-\mathbf{1 5} 8$ and measuring the lesion focus.

Table 1. Average values of the optical density $(M \pm S D)$ in the case of CBCT in the lesion area and the area of the lesion in the study groups.

\begin{tabular}{|c|c|c|c|c|c|c|}
\hline \multirow{3}{*}{ Groups } & \multicolumn{5}{|c|}{$\begin{array}{l}\text { Average HU values obtained with CBCT in the } \\
\text { lesion area }\end{array}$} & \multirow{3}{*}{$\begin{array}{c}\text { Hearth } \\
\text { area } \\
\mathrm{mm}^{2}\end{array}$} \\
\hline & \multirow{2}{*}{ Centre } & \multirow{2}{*}{ Min } & \multirow{2}{*}{ Max } & \multicolumn{2}{|c|}{ Cortical bone } & \\
\hline & & & & \begin{tabular}{|c|}
$\begin{array}{c}\text { Vestibular } \\
\text { surface }\end{array}$ \\
\end{tabular} & $\begin{array}{c}\text { Oral } \\
\text { surface }\end{array}$ & \\
\hline $\begin{array}{l}\text { general } \\
\text { group } \\
\mathrm{n}=30\end{array}$ & $\begin{array}{l}-60.97 \\
\pm 93.40\end{array}$ & & $\begin{array}{c}32.10 \\
\pm 75.25\end{array}$ & & & \\
\hline $\begin{array}{l}\text { group } 1 \\
\text { (granulon } \\
\text { a) } n=26\end{array}$ & $\begin{array}{l}-48.38 \\
\pm 62.42\end{array}$ & $\begin{array}{c}-124.00 \\
\pm 76.23\end{array}$ & $\begin{array}{c}36.22 \\
\pm 66.44\end{array}$ & & & \\
\hline $\begin{array}{l}\text { group } 2 \\
\text { (cyst) } n=4\end{array}$ & $\begin{array}{r}-196.25 \\
\pm 102.24\end{array}$ & & $\begin{array}{c}-4.10 \\
\pm 45.46\end{array}$ & & & $\begin{array}{l}210.65 \\
\pm 24.10\end{array}$ \\
\hline & & $\mathrm{P}=0.002^{*}$ & $\mathrm{P}=0.222$ & $\mathrm{P}=0.647$ & & \\
\hline
\end{tabular}

* - statistically significant difference between the average HUd values in group 1 and in group 2

A preliminary CBCT study was carried out on Planmeca ProMax 3D Max equipment (Finland) with a tube voltage of $90 \mathrm{kV}$, a current strength of $12 \mathrm{~mA}$, an exposure time of 11.00 to 14.00 seconds with a resolution of 200 microns. The study of the periapical lesion was measured in three planes. The units of optical density (HU) were measured on the obtained CBCT images in the area of the lesion: in the center, the minimum and maximum readings of the studied lesion (Fig. 1).

Standard measurements were recorded for the cortical bone without pathological changes in the vestibular and oral surfaces (Table 1). The size of the periapical lesion was determined by measuring the area of the periapical lesion. It was calculated by measuring the focus with two lines drawn strictly perpendicular to each other according to the maximum changes in the destructive process in the periapical region.

The selection of extracted teeth after the CBCT study was carried out according to the following criteria: after tooth extraction, the periapical tissues in the apical part of the tooth had to be preserved and attached to the root for excision biopsy (Fig.2).

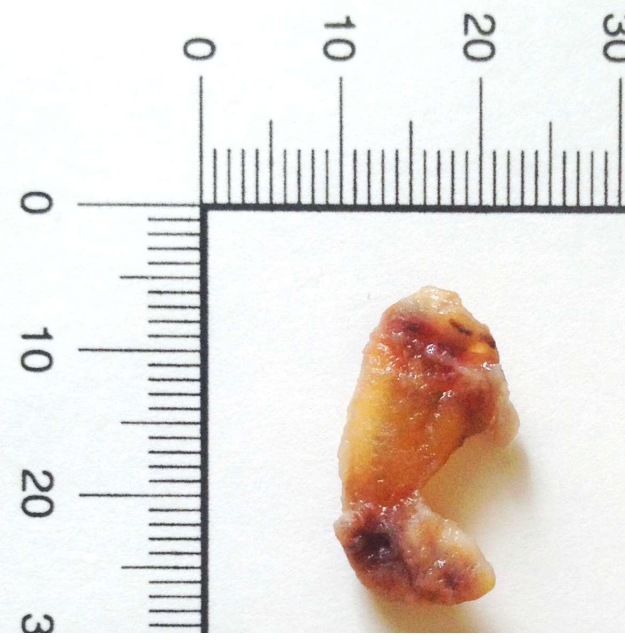

Figure 2. Removed tooth with periapical tissues for excision biopsy.

The histological material was prepared in a $10 \%$ aqueous solution of neutral formalin in a plastic container with a tight lid. After that, decalcification was performed. The resulting histomaterial was immersed in a histological medium using a paraffin filling system.

Histosections with a thickness of 2-3 microns were obtained using a rotary semi-automatic microtome. Dewaxing and immunohistochemical (IHC) research was carried out according to the standard protocol in an automatic mode.

Histopreparations were stained with hematoxylin and eosin, according to Mallory, according to Bilshovsky, according to Pound, according to Van Gieson, the marker p63 was used during immunohistochemical examination.

The analysis and study of the obtained histological preparations was carried out using a Nikon Eclipse E200 light microscope. The histological preparations were photographed using a digital camera, with an increase in $\times 4, \times 10, \times 40, \times 100$. 


\section{THE RESULTS OF THE STUDY AND THEIR DISCUSSION}

All patients were given a preliminary diagnosis of "chronic apical periodontitis" on the basis of a clinical examination and data from a CBCT examination.

The assessment of the HU value demonstrated the presence of negative values for CBCT in the periapical lesion, measured in the center, as well as maximum and minimum $\mathrm{HU}$ values in the lesion. In chronic apical periodontitis, this reflected the version that there is a cavity destructive lesion in this focus, which can contain both liquid and be hollow, all these data speak in favor of a preliminary diagnosis of a root cyst, since there is a cavity in the cyst that can be filled with various exudate. Positive values of $>40 \mathrm{HU}$ with $\mathrm{CBCT}$ in the periapical lesion, measured in the center, as well as maximum and minimum $\mathrm{HU}$ values in the focus, with apical periodontitis, we classified that soft tissues were present in the focus, which could be granuloma.

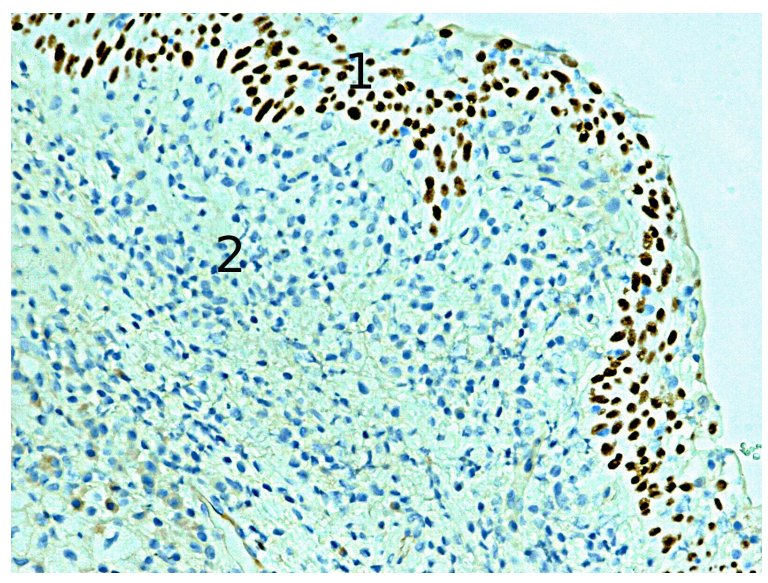

Figure 3. Historiarum. 1-multilayer squamous epithelium 2 - granulation periodontal tissue is represented by fibroblast cells. Stained with hematoxylin-eosin.

Immunohistochemistry with marker p63. vol. 10, approx. 10.

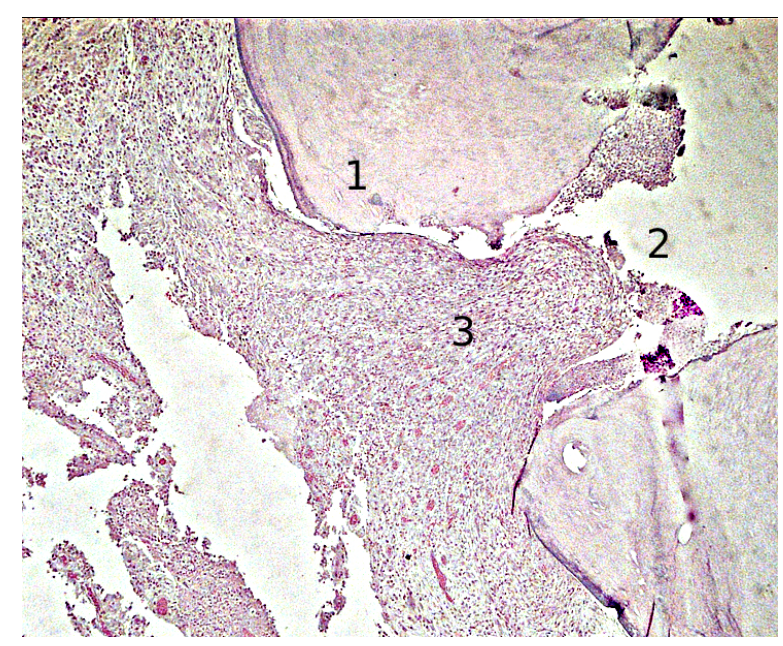

Figure 4. Historiarum. 1-anatomical tip of the tooth root, 2-periodontal granulation tissue with well-developed capillary vessels, 3 -growth of granulation tissue in the lumen of the root canal. Painting with hematoxylin-eosin. About 4, approx. 10.

The study of histological materials showed that, in four samples out of 30 , there was a multilayer flat epithelium, which corresponded to the diagnosis of a root cyst, while HU units in the center of the focus were recorded from -58 to -240 , the minimum values of $\mathrm{HU}$ in the focus ranged from -480 to -265 , the maximum values of $\mathrm{HU}$ in the focus ranged from -31 to 49 , histosections are shown in Figure 3. In 26 histological samples, granulation tissue without signs of epithelization was present in histological sections (Fig. 3, Fig. 4, Fig. 5), while HU units in the center of the focus were recorded from 51 to -186 , the minimum values of $\mathrm{HU}$ in the focus ranged from -246 to 7 , the maximum values of $\mathrm{HU}$ in the focus ranged from -69 to 152.

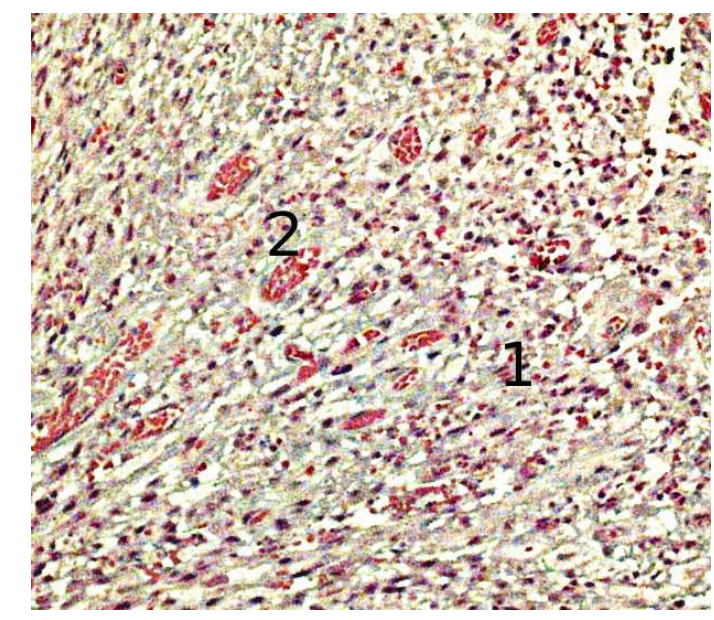

Figure 5. Historiarum. 1-granulation periodontal tissue is represented by fibroblast cells. $2-$ forming vessels of the capillary type. Painting with hematoxylin-eosin. About 20, 10 approx.

The area of the lesion when confirming the diagnosis of a root cyst by histological examination was from $194.6 \mathrm{~mm} 2$ to $253.4 \mathrm{~mm} 2$, which corresponds to the data of Natkin et al. (1984) [17].

The analysis of the obtained data on the optical density of the HU scale measured in different patients of the study group was multidirectional for all six parameters: Center, Min, Max, Vestibular surface, Oral surface, Focal area (Table 1). Preliminary exploratory graphical analysis and verification histological data (confirmation of the cyst) allowed us to conclude that in order to compare the values of optical parameters of cone-beam computed tomography, the studied group of patients should be divided into two groups: group 1 (granuloma) with a sample size of $\mathrm{n}=26$ and group 2 (cyst) with a sample size of $n=4$.

One of the stages of comparing the indicators for the two groups was to determine the average values and compare them. For three indicators: Center, Min, and the Area of the focus, the differences in the average values were statistically significant. The hypotheses were compared using the nonparametric WhitneyManny criterion. There was no statistically significant difference in the mean values for three indicators: Max, Vestibular surface and Oral surface (Table 1). The hypotheses were also compared using the nonparametric Whitney - Manny criterion.

The first three parameters of the CLC of the span diagram from the median are shown in Figure 6. For 
the second three parameters of the CLC, the span diagrams from the median are shown in Figure 7.

The evaluation of the span diagrams shows (Fig. 6) that the indicators Center, Min, and the Area of the focus can be used for differential diagnosis, since the areas of overlap of the values of these indicators are either small or absent.

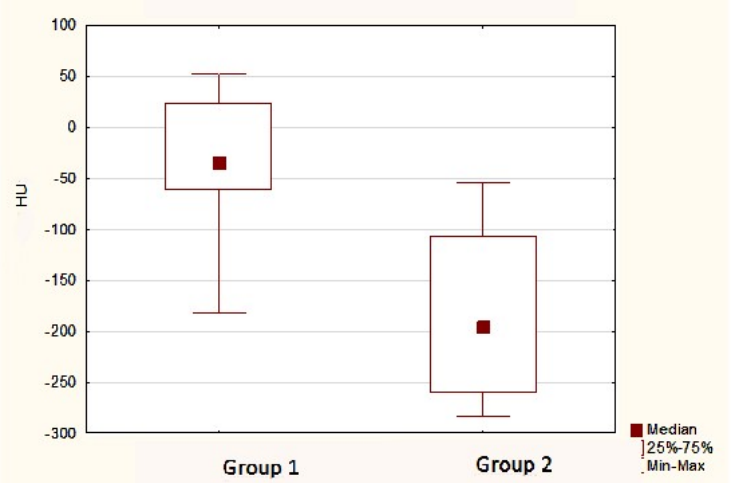

A
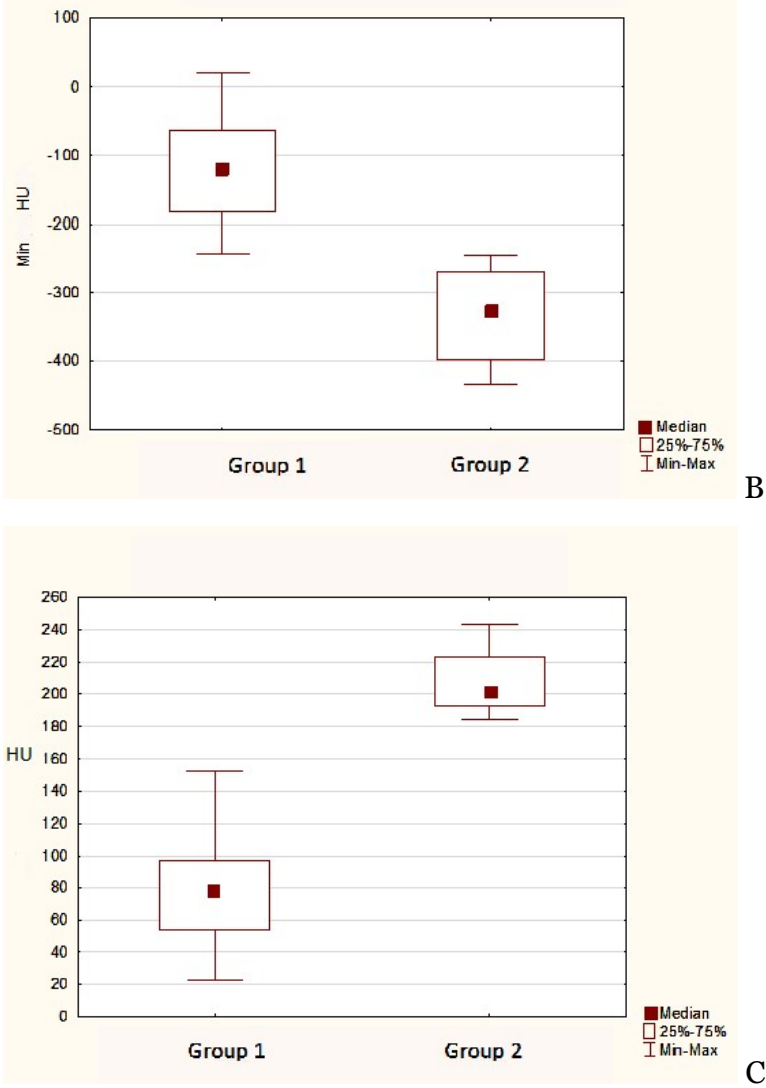

Figure 6. Scale diagrams for indicators: A - Center, B-Min, C-hearth area.

When considering the span diagrams, it follows (Fig. 7) that the Max, Vestibular surface and Oral surface indicators cannot be used for differential diagnosis, since there are significant areas of overlap between the values of these indicators.
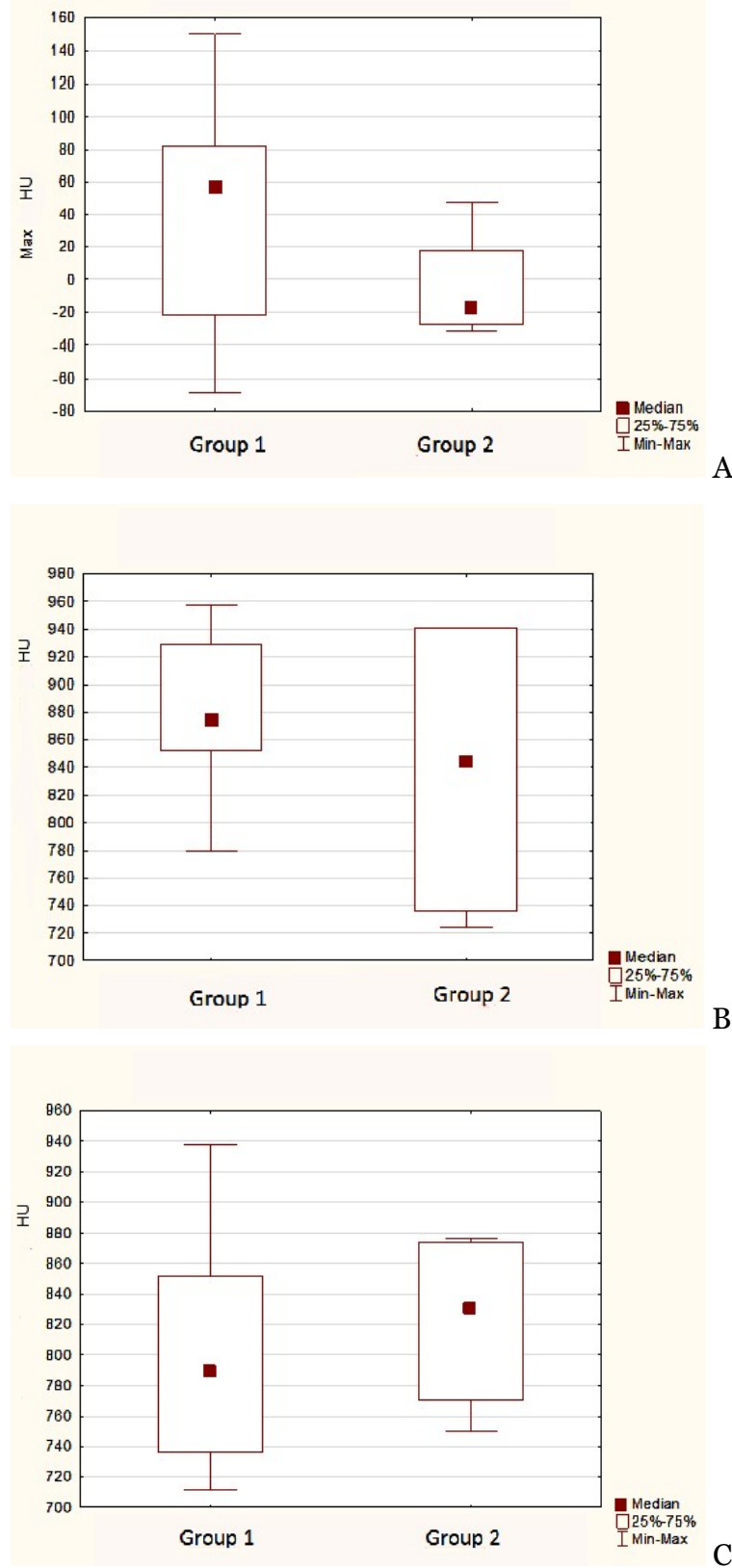

Figure 7. Scale diagrams for indicators: A-Max, B - Vestibular surface B-Oral surface.

In order to detect an informative indicator, ROC analysis (Receiver Operator Characteristic) was used. ROC analysis is a research tool that allows you to analyze the relationship of sensitivity and specificity of the research method in a binary classification, in our case, the granuloma (0) and cyst are binary [5].

The results of the ROC analysis were ROC curves for three optical indicators of CBCT: Center, Min and the Area of the focus.

To compare the effectiveness of optical parameters of CBCT, quantitative characteristics of ROC analysis are given (Table No. 2). These are the following characteristics: AUC or the area under the ROC curve, showing the effectiveness of the parameter for diagnosis, the $95 \%$ confidence interval for AUC, the 
A.A. Adamchik et al., CT in differential diagnosis of chronic periodontitis..., RAD Conf. Proc., vol. 5, 2021, 62-67

optimal threshold of parameter values, sensitivity and specificity.

Table 2. Characteristics of ROC analysis.

\begin{tabular}{|l|c|l|l|l|l|l|}
\hline $\begin{array}{l}\text { Paramet } \\
\text { r }\end{array}$ & AUC & $\begin{array}{l}\text { 95\% } \\
\text { confidenc } \\
\text { intervals } \\
\text { AUC }\end{array}$ & $\begin{array}{l}\text { Optimal } \\
\text { threshold } \\
\text { (HU) }\end{array}$ & $\begin{array}{l}\text { Sensitivity } \\
(\%)\end{array}$ & $\begin{array}{l}\text { Specificit } \\
\text { (\%) }\end{array}$ & $\begin{array}{l}\text { Confidenc } \\
\text { e level P }\end{array}$ \\
\hline Centre & 0.92 & $0.74 \div 1.11$ & -54.0 & 100 & 73.07 & 0.0107 \\
\hline Min & 1.00 & $\begin{array}{c}1.00 \div 1.0 \\
0\end{array}$ & -246.0 & 100 & 100 & 0.0008 \\
\hline $\begin{array}{l}\text { Yearth } \\
\text { rea }\end{array}$ & 1.00 & $\begin{array}{c}1.00 \div 1.0 \\
0\end{array}$ & $\begin{array}{c}196.4 \\
\text { MM }^{2}\end{array}$ & 100 & 100 & 0.0008 \\
\hline
\end{tabular}

\section{CONCLUSION}

CBCT is a fairly informative diagnostic method for early detection of the lesion in chronic apical periodontitis and can classify the form of chronic apical periodontitis: granuloma or cyst. The ability to measure the size, optical density of the focus, allows you to more accurately diagnose the presence of a root cyst.

The most reliable data are the Min indicators with a threshold value of -246 units. HU and the area of the hearth with a threshold value of $194.6 \mathrm{~mm} 2$. The study of diagnostics using the Min indicators and the area of the focus are statistically significant at $\mathrm{P}=0.0008$.

\section{REFERENCES}

1. М.А. Чибисова, Н.М. Батюков, «Методы рентгенологического обследования и современной лучевой диагностики, используемые в стоматологии», Институт Стоматологии, том 88, номер 3, стр. 24-33, 2020.

(M.A. Chibisova, N.M. Batyukov, "Methods of X-ray examination and modern radiation diagnostics used in dentistry", The Dental Institute, vol. 88, no. 3 , pp. 24-33, 2020.)

Retrieved from:

https://elibrary.ru/download/elibrary 44076240 4 279935.p.pdf

Retrieved on: Jun. 15, 2021

2. А.И. Громов, «Проблема точности денситометрических показателей в современной многослойной компьютерной томографии», Медицинская визуализация, но. 3, стр. 133-142, 2016.

(A.I. Gromov et al., "The problem of the accuracy of densitometric indicators in modern multilayer computed tomography”, Medical Vizualization, no. 6 , pp. 133-142, 2016.)

Retrieved from: https://medvis.vidar.ru/jour/article/viewFile/368/3 $\underline{56}$

Retrieved on: Jul. 21, 2021

3. Е. В. Кайзеров, А. В. Холин, М. А. Чибисова, А. А Зубарева, «Дифференциальная клиникорентгенологическая характеристика различных типов одонтогенных кист челюстно-лицевой области», Лучевая диагностика и терапия, но. 1, стр. 11-23, 2018.

(E.V. Kaiserov, A.V. Kholin, M.A. Chibisova, A.A. Zubareva, Differential clinical and radiological characteristics of odontogenic cysts of the maxillofacial region are of different types, Diagnostic radiology and radiotherapy, no. 1, pp. 11-23, 2018.) https://doi.org/10.22328/2079-5343-2018-9-1-1123

4. В.В. Ким, Ю.А. Мингазеев, В.С. Новиков, «Клинический опыт применения метода конусно-лучевой компьютерной томографии в эндодонтии», Эндодонтия Today, том 10, но. 1, стр. 53-56, 2012.

(V.V. Kim, Ju.A. Mingazeeva, V.S. Novikov, "Clinical experience of using the method of cone-beam computed tomography in endodontics", Endodontics Today, no. 1, pp. 53-56, 2012.)

Retrieved from:

https://www.endodont.ru/jour/article/view/709/58

Retrieved on: Jun. 15, 2021

5. И.П. Королюк, «ROC анализ (операционные характеристики наблюдателя): базовые принципы и применение в лучевой диагностике», Медицинская визуализация, но. 6, стр. 113-123, 2013.

(I.P. Korolyuk, "ROC analysis (Receiver Operating Characteristic Analysis): basic principles and application in diagnostic radiology", Medical Vizualization, no .6, pp. 113-123, 2013.)

Retrieved from:

http://vidar.ru/Article.asp?fid=MV $2013 \quad 6 \quad 113$

Retrieved on: Jun. 15, 2021

6. А.Ю. Ногина, «Особенности применения метода конусно-лучевой компьютерной томографии в эндодонтической практике», Эндодонтия Today, но. 2, стр. 50-54, 2015.

(A.Yu. Nogina, "Application features of the conebeam computerized tomography method in endodontic practice", Endodontics Today, no. 2, pp. 50-54, 2015.)

Retrieved from:

https://www.endodont.ru/jour/article/view/436/35 o

Retrieved on: Jun. 16, 2021

7. Г.И. Ронь и др., «Количественная оценка трехмерной реконструкции челюстно-лицевой области и возможности проведения денситометрии на конусно-лучевом компьютерном томографе в динамическом наблюдении пациентов с заболеваниями пародонта», Институт Стоматологии, но. 4, стр. 55-57, 2015.

(G.I. Ron et al., "Quantitative assessment of threedimensional reconstruction of the maxillofacial region and the possibility of densitometry on a conebeam computed tomograph in the dynamic observation of patients with periodontal diseases", The Dental Institute, no. 4, pp. 55-57, 2015.)

Retrieved from:

https://instom.spb.ru/catalog/article/10380/?view= pdf

Retrieved on: Jun. 15, 2021

8. О.Б. Селина и др., «Сравнительный анализ данных традиционной рентгенографии и дентальной конусно-лучевой компьютерной томографии при диагностике хронического гранулирующего периодонтита», Российский стоматологический журнал, том 20, номер 4, стр. 201-205, 2016.

(O.B. Selina et al., "Comparative analysis of traditional dental radiography and cone beam computed tomography in the diagnosis of chronic granulating periodontitis", Russian Journal of Dentistry, vol. 20, no. 4, pp. 201-205, 2016.) Retrieved from: 
A.A. Adamchik et al., CT in differential diagnosis of chronic periodontitis..., RAD Conf. Proc., vol. 5, 2021, 62-67

https://rjdentistry.com/1728-

2802/article/view/42068

Retrieved on: Jun. 15, 2021

9. С. В. Сирак и др., «Морфологические и гистохимические изменения в околокорневых гранулемах при хроническом гранулематозном периодонтите», Медицинский алфавит, том 2, но. 11, стр. 48-51, 2017.

(S.V. Sirak et al., "Morphological and histochemical changes in oculocardiac granulomas in chronic granulomatous periodontitis", Medical Alphabet, vol. 2, no. 11, pp. 48-51, 2017.)

Retrieved from:

https://www.med-

alphabet.com/jour/article/view/178/178

Retrieved on: Jun. 15, 2021

10. С. В. Сирак и др., «Экспериментальная оценка регенераторного потенциала тканей пародонта», Пародонтология, том 21, но. 3, стр. 15-18, 2016.

(S.V. Sirak et al., "Experimental evaluation of the regenerative potential of periodontal tissues" Parodontology, vol. 21, no. 3, pp. 15-18, 2016.) Retrieved from:

https://www.parodont.ru/jour/article/view/187/187 Retrieved on: Jun. 16, 2021

11. М.А. Чибисова, А.А. Зубарева, А.Л. Дударев, Е.В. Кайзеров, «Современные подходы к дифференциальной рентгенологической характеристике клиникоодонтогенных кист челюстно-лицевой области различных этиопатогенетических типов», Институт Стоматологии, но. 3, стр. 78-83, 2017.

(M.A. Chibisova, D.V. Zubarev, A.L. Dudarev, E.V. Kajzerov, "Modern approaches to the differential clinical and radiological characteristics of odontogenic cysts of the maxillofacial region of various etiopathogenetic types", The Dental Institute, no. 3, pp. 78-83, 2017.)

Retrieved from:

https://instom.spb.ru/catalog/article/10954/?view= pdf

Retrieved on: Jun. 15, 2021

12. J. Guo et al., "Evaluation of the reliability and accuracy of using cone-beam computed tomography for diagnosing periapical cysts from granulomas", J. Endod., vol. 39, no. 12, pp. 1485-1490, 2013. https://doi.org/10.1016/j.joen.2013.08.019
13. W.D. Grimm et al., "Neural crest-related stem cells of oral origins in vitro and used in osteoporotic sheep model for being investigated due to therapeutic effects in alveolar bone regeneration", Medical News of North Caucasus, vol. 11, no. 2, pp. 192-196, 2016. https://doi.org/10.14300/mnnc.2016.11034

14. C.S. De Rosa et al., "Differentiation of periapical granuloma from radicular cyst using cone beam computed tomography images texture analysis", Heliyon, vol.6, no. 10, article no. E05194, 2020. https://doi.org/10.1016/j.heliyon.2020.e05194

15. P.N.R. Nair, U. Sjögren, E. Schumacher, G. Sundqvist, "Radicular cyst affecting a root-filled human tooth: a long-term post-treatment follow-up", Int. Endod. J., vol. 26, no. 4, pp. 225-233, 1993. https://doi.org/10.1111/j.1365-2591.1993.tbo0563.x PMid: 8225641

16. P.N.R. Nair, "New perspectives on radicular cysts: do they heal?", Int. Endod. J., vol. 31, no. 3, pp. $155-160,1998$

https://doi.org/10.1046/j.1365-2591.1998.00146.x PMidID: 10321160

17. E. Natkin, R.J. Oswald, L.I. Carnes "The relationship of lesion size to diagnosis, incidence and treatment of periapical cysts and granulomas", Oral Surg., Oral Med., Oral Pathol., vol. 57, no. 1, pp. 82-94, 1984. https://doi.org/10.1016/0030-4220(84)90267-6 PMid: 6364008

18. S. Patel at al., "European Society of Endodontology position statement: The use of CBCT in Endodontics", Int. Endod. J., vol. 47, no. 6, pp. 502-504, 2014. https://doi.org/10.1111/iej.12267 PMid: 24815882

19. P.A. Rosenberg et al., "Evaluation of pathologists (histopathology) and radiologists (cone beam computed tomography) differentiating radicular cysts from granulomas", J. Endod., vol. 36, no. 3, pp. 423-428, 2010. https://doi.org/10.1016/j.joen.2009.11.005 PMidID: 20171356

20. J.H.S. Simon, "Incidence of periapical cysts in relation to the root canal", J. Endod., vol. 6, no. 11, pp. $845-847,1980$. https://doi.org/10.1016/Soog9-2399(80)80039-2 PMid: 6935342 